\title{
Rhetoric vs realism in economic methodology: a critical assessment of recent contributions
}

\author{
Fabienne Peter
}

\begin{abstract}
This paper reviews the relatively new debate on rhetoric and realism in economic methodology, concentrating on its main exponents: Deirdre McCloskey on the side of rhetoric, Tony Lawson as the advocate of critical realism, and Uskali Mäki, arguing for a combination of rhetoric and realism. The review highlights a blind spot in the debate, namely the opportunity to rethink critically the project of epistemology.
\end{abstract}

Key words: Rhetoric, Realism, Philosophy of economics, Social epistemology FEL classifications: A11, B40

Currently, one can observe a shift of interest in debates about economic methodology. 'Rhetoric or realism?' tends to replace - at least implicitly - the controversies over the advantages and disadvantages of variants of the Popperian philosophy of science, that have tended to dominate economic methodology from the 1970 s to the late $1980 \mathrm{ss}^{1}$ The Popperian philosophy of science, with its emphasis on deductivism and falsificationism, stands squarely in the positivist tradition. Characteristic of positivism is the preoccupation with epistemological standards - for example, Popper's falsificationism - which are supposed to determine what constitute valid scientific arguments and hence knowledge. ${ }^{2}$ Rhetoric and realism are understood as alternatives to positivism. ${ }^{3}$

This paper presents a comparative review of recent contributions in rhetoric and realism. It concentrates on the main exponents: Deirdre McCloskey on the side of rhetoric, and

Manuscript received 1 November 1999; final version received 27 July 2000.

Address for correspondence: Fabienne Peter, Department of Economics, University of Basel, Petersgraben 51, 4003 Basel, Switzerland; email: fpeter@hsph.harvard.edu

* University of Basel and Harvard Center for Population and Development Studies. For helpful, sometimes extensive comments and interesting discussions I am very grateful to Steve Fleetwood, Tony Lawson, Uskali Mäki and Julie Nelson. I am also grateful to the participants of the Workshop on Realism and Economics at King's College, Cambridge, in particular to Jochen Runde and to seminar participants at Harvard University and at the Catholic University of Louvain. In addition, I have received helpful comments from anonymous referees.

${ }^{1}$ The standard reference is Blaug (1980). See also Redman (1991) for a book-length survey of mainstream economic methodology, and Dow (1997A).

${ }^{2}$ Habermas (1968) provides a thorough discussion of how, with positivism, philosophy of science was reduced to epistemology. Epistemology can be defined as the '[e]nquiry into the nature and ground of experience, belief and knowledge' (Lacey, 1986, p. 63).

${ }^{3}$ Caldwell (1982) offers an early attempt to move beyond positivism and includes an excellent review of the development of positivist philosophy of science in economics. 
Tony Lawson and Uskali Mäki who argue in different ways for scientific realism in economics.

Rhetoric became an issue in economics in the mid-1980s, when McCloskey's article 'The Rhetoric of Economics' appeared, followed by a book with the same title (McCloskey, 1983, 1985). ${ }^{1}$ Also around that time, Arjo Klamer's Conversations with Economists was published (Klamer, 1984A).$^{2}$ The rhetoric approach highlights the role of argumentative persuasion in scientific discourse and criticises the legacy of what McCloskey calls alternatively 'modernism' or 'positivism' in economics. It distinguishes between the official methodology - based on epistemological standards of what constitutes scientific knowledge - and the unofficial methodology — what economists actually practice. It is argued that the latter resembles more an ongoing discourse or conversation, where many forms of reasoning and many styles of argumentation prevail. ${ }^{3}$

The philosophy of scientific realism, representing the other side of the debate, has many variants. In some form or other, realism has been an integral part of the philosophy of economics for a long time already. But it is only recently, partly in reaction to relativist movements, that realism is being proposed as a distinct philosophy of economics. In a nutshell, the realist approach emphasises that, to make sense of the endeavour of economic science, it has to be understood as an attempt to explain economic reality, to discover truth about entities that exist objectively - independently of scientific theories. Even if the epistemic relativism that the rhetoric approach defends is granted, economic discourse is still about something. Ontological assumptions-assumptions about the nature of the (social) world and about the possibility of obtaining knowledge about the worldshape and constrain the way economists explain, or should explain. The realist position is advocated most prominently by Lawson in a series of articles (e.g., 1987, 1989, 1992A, 1992B, 1994, 1995A, 1995B, 1998, 1999A, 1999B) as well as in his recent book Economics and Reality (Lawson, 1997), and by Mäki (e.g., 1988A, 1988B, 1989, 1990A, 1990B, 1992A, 1992B, 1993A, 1994, 1996, 1998A, 2000). ${ }^{4}$

The characterisation of scientific realism given here is deliberately weak, since Lawson's critical realism has not, in fact, much in common with Mäki's approach. Critical realism advocates a particular ontological foundation for economics. The thesis is that, if economists would take this ontology into account, their explanations would be more successful. The argument for critical realism in economics, though self-contained, borrows from the work of Roy Bhaskar-in particular from the philosophy of 'transcendental realism' that Bhaskar developed for the natural sciences. ${ }^{5}$ Mäki's version of realism is

\footnotetext{
${ }^{1} \mathrm{McCloskey} \mathrm{has} \mathrm{since} \mathrm{published} \mathrm{four} \mathrm{more} \mathrm{books} \mathrm{on} \mathrm{rhetoric:} \mathrm{The} \mathrm{Writing} \mathrm{of} \mathrm{Economics} \mathrm{(1986),} \mathrm{If} \mathrm{You're} \mathrm{So}$ Smart (1990), Knowledge and Persuasion in Economics (1994), and, most recently, The Vices of Economists-The Virtues of the Bourgeoisie (1996), as well as numerous articles. In McCloskey (1994), she responds extensively to her critics. Just recently, she published a revised second edition of The Rhetoric of Economics.

${ }^{2}$ See also Klamer (1984B, 1988A, 1988B). On rhetoric in economics, see furthermore, for example, Amariglio (1990) and Rossetti (1992).

${ }^{3}$ Some of the reactions to the rhetoric approach are collected in Consequences of Economic Rhetoric (Klamer et al., 1988). See also Caldwell and Coats (1984), Mäki (1988A), Rappaport (1988) and Rosenberg (1988) in a special symposium in Economics and Philosophy. Rhetoric is the dominant theme in several recent collected volumes on economic methodology, e.g., Samuels (1990), Henderson et al. (1993) and Backhouse (1994).

${ }^{4}$ Several symposia on critical realism have been published in economic journals; most recently in Review of Social Economy, vol. 56, no. 3, 1998, and The fournal of Post-Keynesian Economics, vol. 22, no. 1; they include either a response or an introduction by Lawson (Lawson, 1998, 1999C). Two earlier symposia are reprinted in Fleetwood (1999).

${ }^{5}$ See, for example, Bhaskar $(1978,1986,1989)$. For an introduction to Bhaskar's philosophy of science, see Outhwaite (1987) and Collier (1994). See also the reader edited by Archer et al. (1998).
} 
closer to the rhetoric approach in many respects, but deviates from it in arguing that economic discourse needs a realist foundation. Like critical realism, it also stresses the importance of ontological considerations, primarily, however, in relation to the role and interpretation of truth in economic explanation.

Rhetoric and realism are increasingly assessed comparatively (e.g., Mäki 1988A, 1988B, 1993A, 1995, 2000; Boylan and O'Gorman, 1995), and this can probably be taken as a sign that interest in economic methodology is shifting to new questions. Perhaps the most interesting set of issues that the rhetoric vs realism debate raises crystallises around the question of what should guide the process of knowledge evaluation and legitimisation in economics. All parties to the debate agree that the Popperian preoccupation with epistemological standards is too narrow and that there is a need for an alternative framework. But, on how to break free from this heritage and how to re-think the nature of scientific discourse in economics, there is little agreement. McCloskey is primarily concerned with the use of epistemology to demarcate science and non-science. The main problem according to Mäki and Lawson lies in the neglect of ontological considerations that resulted from the preoccupation with epistemology.

\section{Rhetoric, realism or both?}

Lawson, McCloskey and Mäki all share the view that there is need for an alternative framework for economic methodology. Mäki (1993B, p. 6) writes:

I believe that the Popperian dominance has led to a misallocation of intellectual resources in economic methodology. Armed with Popperian questions and tools, economic methodologists have had little to say about many relevant issues in economics, such as the actually effective grounds for holding beliefs, the kinds and roles of inductive reasoning, the structure of explanations, the perennial issue of realisticness, and the nature of metaphysical commitments involved in actual research practice.

McCloskey and Lawson in particular understand their frameworks as comprehensive alternatives to Popperian economic methodology. In the following sections, I shall first review Lawson's and McCloskey's objections to positivism, and then briefly discuss each of the three approaches.

\subsection{Against the positivist legacy in economics}

Given the opposing stands taken in what Lawson and McCloskey respectively consider to be a more appropriate methodology for economics, it is perhaps surprising to see that their critique focuses on the same two key characteristics of positivist economic methodology. The two issues in question are an over-emphasis on epistemological rules on the one hand, and on prediction on the other.

Less surprisingly, their arguments and even their starting-points are very different. McCloskey starts with an examination of the practices of economists. Lawson, in contrast, starts with an examination of the nature of the subject matter of economics. While the methodological conclusions drawn from the second approach are clearly prescriptive in orientation, this is not to say that the first approach is automatically purely descriptive. It may be-and in fact is - used for prescriptive purposes as well.

For McCloskey, positivism is the incarnation of modernism in the realm of philosophy of science. The rhetoric approach sets out to challenge the modernist/positivist methodological self-understanding of economics. One of its principal concerns is with the 


\section{4} F. Peter

demarcation problem: it attacks the modernist belief that there is a clear-cut division between science and non-science based on the ways knowledge is produced in the two domains. The rhetoric project is directed both against the idea that scientific knowledge is different in nature from other ways of knowing, and against the hierarchy that was established between Science (big S) and non-science.

As mentioned, the rhetoric approach takes as its starting-point the analysis of the actual practices of economists - their written texts as well as their oral communications. ${ }^{1}$ From the perspective of rhetoric, economics is an ongoing conversation; it is essentially literary in character. Economists, just like everybody else trying to make a convincing argumentwhether in Science or outside-rely on reasoning by analogy, metaphors, appeals to authority, introspection, symmetry, etc. ${ }^{2}$ Their analysis of how economists argue reveals that the grounds on which the acceptability of scientific theories is determined have nothing to do with positivist epistemological rules. Economists do not practice what they preach is their conclusion. Economists do not set out to formulate testable hypotheses and then attempt to falsify them by means of relevant empirical evidence. According to McCloskey, it is not accidental that the official methodology is not practised. For one thing, it is fundamentally flawed in its description of scientific activity. And secondly, McCloskey agrees with Feyerabend (1975) that it is also undesirable as an ideal of scientific inquiry. Science would come to a standstill if positivism were implemented.

Lawson agrees with McCloskey that positivist epistemological rules paint a mistaken picture of how knowledge is obtained. But their common ground does not go much further. According to Lawson, the main problem with positivism is that it neglects ontological considerations. ${ }^{3}$ Echoing Bhaskar, he calls the tendency to subsume ontological issues under epistemology an 'epistemic fallacy' (Lawson, 1997, p. 33). It is a fallacy because every philosophy, every approach to science, is necessarily based on some ontology.

Lawson is primarily concerned with the explanatory modus underlying deductivism. As formulated in the so-called covering law models, deductivism requires that phenomena be explained by combining a set of initial conditions with appropriate universal laws: if $x$, then $y$. Underlying the covering law models is an ontology of 'empirical realism' (Lawson, 1997, p. 19). It describes the world as an ensemble of atomistic events, accessible through sense data and constant conjunctions between them.

In contrast to McCloskey, Lawson believes that economists are trying very hard to fulfil the deductivist requirement. Deductivism, in his view, is more than a shabby cloak, and determines in particular economic 'theory' (Lawson, 1997, p. 103). At the same time, he agrees with McCloskey that there is a discrepancy between theory and practice. $\mathrm{He}$ interprets it differently, however: according to Lawson, this discrepancy reveals the failure of deductivism to take into account the particular ontology of the social realm.

Lawson is very critical of the whole project of mainstream economics. In his view, the current state of economics is characterised by lack of success and irrelevance. This is why he would not want to start with an examination of the practices of economists. The critical realist project in economics is an attempt to show that economics could be made more successful if economists would give up their commitment to deductivism, and recognise

\footnotetext{
${ }^{1}$ In this respect, it differs from 'anthropological' approaches to the study of science, which look over scientists' shoulders in their daily practice. The anthropological approach was pioneered by Latour and Woolgar (1979).

${ }^{2}$ See McCloskey (1985, pp. 42ff. and ch. 4).

${ }^{3}$ Lawson (1997, p. 33) writes: '[T] he basic error underpinning the now discredited positivist conception of science is precisely the abandonment of explicit ontological reasoning.'
} 
the importance of ontological reasoning and the constraints on explanation that arise from the ontology of the social world.

The argument for critical realism that Lawson develops in Economics and Reality (Lawson, 1997) draws from Bhaskar's work. Even though Bhaskar's work is less frequently mentioned in articles Lawson has published since then, it will be helpful to sketch the main elements of Bhaskar's philosophy as they are present in critical realism as it stands today.

One of Bhaskar's principal claims is that the ontology of empirical realism cannot account for the success of the natural sciences. Transcendental realism, the alternative account Bhaskar has developed, uses the analysis of the experimental practice that is characteristic of most of natural science as its starting-point. Experiments work by constructing closed worlds. Scientific 'laws' are formulated on this basis. Typically, however, the regularities found in experiments do not hold in the real-open-world. To illustrate this gap, Bhaskar and Lawson point to the example of a falling autumn leaf (Lawson, 1997, p. 22).

What must the world be like for this scientific practice to be successful? The ontology of empirical realism seems inadequate. Instead, Bhaskar proposes the following stratified theory of reality. ${ }^{1}$ The first level is the empirical - that of experience and impression. The second level is that of the actual - the level of actual states of affairs and events. The analysis of the scientific practice of the natural sciences shows that regularities operate hidden from our immediate experience; we only perceive their effects. Thus there is a third level, called the non-actual, or the real. This is the level of mechanisms, structures, powers, and tendencies that produce the events and states of affairs of the actual level, but which may not always be directly observable.

Underlying this assertion is a causal criterion of reality which supplements the more common perceptual one. According to the causal criterion, things that have an effect are real. They exist and act independently of our perception of them at the actual level. ${ }^{2}$

The philosophy of transcendental realism thus suggests that the (natural) world is composed of structured and intransitive objects. They are structured in the sense that they cannot be reduced to actual events and their patterns- this in contrast to the ontology of empirical realism. And they are intransitive in the sense that they exist and operate (more or less) independently of our knowledge of them.

Transcendental realism postulates that the objects of scientific explanation must be these mechanisms, structures, powers and tendencies which operate at the non-actual level. It follows that the explanation of actual phenomena requires an attempt to bridge the gap between the non-actual and the actual. The kind of reasoning involved is called retroduction, distinct both from deduction and induction. Starting from the insights, intuitions, etc. we have about actual events, explanation then consists of the attempt to understand what kind of mechanisms, tendencies and structures could be responsible for bringing about these actual events. Knowledge produced this way can then form the basis for further explanations. Bhaskar emphasises that, inevitably, knowledge produced through retroductive reasoning is fallible; the production of knowledge is a social process and historically situated. It is thus likely that our knowledge of (intransitive) objects changes over time. To put it differently, knowledge has both an intransitive and a transitive dimension. ${ }^{3}$

\footnotetext{
${ }^{1}$ See Bhaskar (1978); see also Lawson (1997, p. 20ff.).

${ }^{2}$ See Lawson (1997, p. 31).

${ }^{3}$ On this see Bhaskar (1989, ch. 5) and, more extensively, Bhaskar (1978).
} 
As we shall see below, Lawson sees the nature of the social world as similarly stratified, structured, and fundamentally open-without denying that the social world differs in important ways from the natural world-and the argument for critical realism in economics builds on these pillars.

Lawson's and McCloskey's arguments against positivist epistemology translate immediately into a critique of the emphasis on prediction that has prevailed in economic methodology since Milton Friedman's influential piece 'The Methodology of Positive Economics' (Friedman, 1953). But again, the reasonings are very different. McCloskey summarises her critique with what she calls the American question, 'if you're so smart, why ain't you rich?' ${ }^{1}$ It is basically an application of the well-known economic argument that there is 'no free lunch': if prediction were possible, the market itself would provide it. Here, to McCloskey's delight, economics defeats itself. Furthermore, the emphasis on prediction is simply a relic of the hope that Science could produce a superior form of knowledge. The rhetoric approach shows that economists should be more modest and understand their discipline as historical and interpretative.

Lawson's rejection of prediction is a direct implication of the argument against the covering law model of scientific explanation. Under this model, explanation is symmetrical to prediction-prediction is simply ex ante and explanation ex post. In the transcendental/critical realist approach, this symmetry is broken and explanation is revalued. Explanation is geared towards uncovering the working of mechanisms at the non-actual level. Because of the fundamental openness of the (social) world, it remains undetermined which mechanisms actually realise their potential. In the social sciences, to deny this openness is to fail to take seriously the human capacity for choice. If prediction and explanation are not seen as symmetrical, the explanation of an actual phenomenon does not entail that it could have been predicted (Lawson, 1997, pp. 285ff.).

\subsection{Rhetoric}

What are the implications of rhetoric for economic discourse? It follows from the emphasis on the discursive nature of science that one of the most important questions is how to keep the conversation in flow. ${ }^{2}$ If one follows McCloskey, mainstream methodology has to be judged as not only irrelevant and mistaken, but counter-productive as well, because it arbitrarily constrains the free flow of the scientific discourse. McCloskey's point is not that deductive reasoning or attempts to falsify hypotheses are wrong as such. Only, they should not receive priority over other forms of reasoning. Her argument is directed against any rule-bound Methodology (big M) in economics and in science in general. ${ }^{3}$ Their only effect is to exclude certain forms of argumentation and to privilege others, whereby those latter do not require any further substantiation. Any rule-bound Methodology will inevitably become rigid over time, thus doing nothing but hindering the discourse. The same thing will happen if Methodology is used not only to demarcate Science from nonscience, but also to circumscribe the boundaries of different disciplines. Without these artificial constraints, economists would be forced to argue more carefully. In McCloskey's view, this could only work to the improvement of the discipline-both in its own terms and in terms of how it is understood (and judged) by outsiders. ${ }^{4}$

McCloskey identifies rhetoric as the realm of persuasion (McCloskey, 1994, p. 41). A

\footnotetext{
${ }^{1}$ If You're so Smart is also the title of her third book on rhetoric (McCloskey, 1990).

2 A section title in The Rhetoric of Economics reads: 'Good Science is Good Conversation'.

${ }^{3}$ See McCloskey (1985, ch. 2).

${ }^{4}$ On this, see McCloskey (1985, ch. 10; 1990).
} 
central tenet of the rhetoric approach is that the criteria for assessing the validity of scientific arguments emerge within the discourse itself-beyond the actual scientific discourse there is no 'safe metalinguistical level' (McCloskey, 1994, p. 201). It follows that what determines the acceptability of arguments - in science as well as in other social spheres-is the persuasion of the participants in the conversation. The only constraint on scientific discourse that McCloskey recognises is what she calls Sprachethik: a framework of overarching moral norms that should guide all conversations. ${ }^{1}$ She lists the following norms (McCloskey, 1985, p. 24):

don't lie; pay attention; don't sneer; cooperate; don't shout; let other people talk; be open-minded; explain yourself when asked; don't resort to violence or conspiracy in aid of your ideas.

The norms of Sprachethik are invoked to ensure that persuasion is uncoerced, and not achieved by means of manipulation, pressure, etc.

\subsection{Critical realism}

Lawson starts by spelling out the elements of what he sees is an appropriate ontology for the social realm. He stresses on the one hand the human capacity for choice. ${ }^{2}$ If taken seriously, it implies that individuals could always have acted differently and that the social world is open in a way similar to the natural world. According to Lawson, a fundamental inconsistency of mainstream economics is that although it puts individual choice at centre stage, it ultimately denies it by modelling individual agency in a way that allows for only one (rational) action. If human choice is real, it has to be treated as a potential, as a capacity, of which we cannot know in advance whether and how it is going to be actualised. $^{3}$

On the other hand, while individual agency is important, it cannot be understood independently of the social structures in which it is embedded. Individuals do not choose or act in a vacuum. It is the social setting that enables certain choices (and prevents others), and it is only in the light of this connection that individual choices make sense. ${ }^{4}$

Rejecting methodological individualism, Lawson stresses that individual choices are not simply determined by social structures. Social rules can be broken and social institutions may change over time. Similarly, although individual behaviour is seen as being heavily reliant on routines and habits, those too can be broken. On the basis of the openness of the social world resulting from the individual capacity for choice on the one hand, and the importance of social structures for individual agency on the other, Lawson suggests that the concept of a stratified reality applies to the social realm as well. The objects of knowledge in the realm of the social sciences seem to be structured and intransitive in a way similar to those of the natural realm.

The next step is to show how many of the problems in economics today can be interpreted in this light. As mentioned, according to Lawson, economics is unsuccessful, and not accidentally so, because of its deductivist methodology. He distinguishes himself from other authors who are critical of the project of mainstream economics by arguing only at the methodological level, not at the substantive level:

\footnotetext{
${ }^{1}$ She claims that the term is borrowed from Habermas, but her interpretation of Habermas is rather sloppy. For an analysis of this issue, see Mäki and Vromen (1996).

${ }^{2}$ The ontology of human agency is laid out in Lawson (1997, p. 174ff.).

${ }^{3}$ Davidson (1980) makes a similar argument.

${ }^{4}$ Lawson (1997, p. 63) writes: 'human agency is not only intentional causality: it is embedded intentional causality'.
} 


\section{8}

F. Peter

My central thesis is briefly stated. The essence of contemporary mainstream economics does not lie at the level of substantive theory as most of its critics suggest, but at the level of methodology. ${ }^{1}$

Lawson looks at the cases of economic theory, econometrics, and with less explicit emphasis, at the field of economic methodology itself. ${ }^{2}$ The goal is to show how difficulties and new developments within economic theory (limitations of rational choice theory and of equilibrium analysis) and econometrics (the Lucas critique) can be better understood from the angle of critical realism. It follows that these problems will remain as long as the positivist foundations with its associated neglect of ontology, reduction of scientific knowledge to atomistic facts and their constant conjunctions, and thus overemphasis on prediction, and-at the epistemological level-methodological individualism, are not abandoned.

The argument uses the parallels between the ontology of the natural realm and of the social realm strategically, to establish that economics can be a science just like the natural sciences. Moreover, building on Bhaskar's argument that transcendental realism can account for the success of the natural sciences while positivism cannot, Lawson conjectures that economics could be more successful if it would abandon positivist/ deductivist methodology and recognise the significance of ontological considerations and their impact on explanation.

Two general particularities of the social sciences as compared with the natural sciences should be noted here. ${ }^{3}$ First, in economics and in the social sciences in general, experimentation is most of the time not possible. This implies that it is impossible to construct closed worlds in which a certain mechanism could be isolated. Explanation in economics thus cannot proceed detached from the open and ever-changing social world. This will render studying and identifying the working of single mechanisms in isolation more difficult.

What, then, could be starting-point for explanation in economics? Lawson sees the answer in what he calls demi-regularities - 'demi-regs' for short, a concept that goes beyond Bhaskar's original framework. A demi-reg is (Lawson, 1997, p. 204)

a partial event regularity which prima facie indicates the occasional, but less than universal, actualization of a mechanism or tendency, over a definite region of time-space. The patterning observed will not be strict if countervailing factors sometimes dominate or frequently co-determine the outcomes in a variable manner. But where demi-regs are observed there is evidence of relatively enduring and identifiable tendencies in play.

Demi-regs are akin to Nicolas Kaldor's notion of stylised facts. Lawson uses the term 'demi-reg' to stress the difference from the way the term is used in current economic discourse. Demi-regs are regularities actually observed in the economic world, not just fictional little stories. Though different from the constant conjunctions sought after in a deductivist science, they are sufficiently widespread and general patterns in the socioeconomic world which, once recognised, can inspire theorising about possible underlying mechanisms. More specifically, it is the 'contrastive demi-regs' that could provide the starting-point for economic explanation-those partial regularities which stand out with respect to our common expectations and accepted beliefs. ${ }^{4}$

\footnotetext{
${ }^{1}$ Lawson (1997, p. 282).

2 The arguments appeared first in several papers and are now summarised in part II of Economics and Reality.

${ }^{3}$ See Bhaskar (1979).

${ }^{4}$ In earlier contributions (e.g., Lawson, 1989), Lawson used the terminology of stylised facts rather than of demi-regs. An expanded account of the role of contrastive demi-regs in economic explanation is given in Lawson (1999A).
} 
A second particularity of the social sciences arises from the effect human agency has on social structures. While, in the natural sciences, scientific realism asserts that the objects of scientific knowledge exist and act independently of scientific investigation, in the social sciences it is important to see that, while we know that social structures are real by virtue of the effects they are having, they do not exist independently of cognition and human agency. It follows that human agency and social structures are deeply interlinked-a perspective that stands in contrast to both 'voluntarism' (Max Weber) and Durkheimian 'reification' of social structures. ${ }^{1}$ Linking cognition and human agency and social structures in this way has implications for the contribution social science, or economics, can make to 'intended [social] change'. ${ }^{2}$ I shall come back to this issue below.

\subsection{Rhetoric with realism}

The third approach I would like to discuss is Mäki's. Mäki is working on two fronts. On the one hand, he analyses the rhetoric project and contrasts it to a realist philosophy of science. ${ }^{3}$ On the other, he studies the implications of a realist philosophy of economics in its own right. ${ }^{4}$

With respect to rhetoric, in McCloskey's interpretation, all that we can know about the world is necessarily contained in a discourse about the world. Only the ethical norms of conversation, which should ensure that persuasion is indeed uncoerced, constrain this discourse. Sprachethik aside, at the philosophical level, this discourse cannot be anchored anywhere. Mäki disagrees with the last claim.

In Mäki's terminology, the realm of rhetoric and persuasion is identified with 'the transference of plausibility by means of arguments' Mäki (1993A, p. 27; italics omitted). Mäki's point is that, understood this way, persuasion affects the beliefs people hold. On this basis, Mäki argues for a role for persuasion that is more limited than in McCloskey's interpretation of rhetoric. He agrees with McCloskey on the importance of persuasion in the domains of justification and discovery. But he considers it a mistake to extend it to that of truth.

To put it differently, while Mäki has no problems with the coherence theory of justification that he identifies in McCloskey's rhetoric approach, he would combine it with a correspondence theory of truth. The latter entails that ' $[\mathrm{t}]$ he truth of a statement $\mathrm{S}$ consists in its correspondence with objective (i.e., S-independent) reality'. 5

McCloskey's mistake, in Mäki's view, is to treat truth as an epistemic matter: she collapses truth and justification. Furthermore, she fails to distinguish between the rhetorical functions of language-aimed at persuasion-and the representational functions-prevalent in the search for truthfulness (Mäki, 1993A, pp. 36f.). Just because we can never know whether or not a statement or belief is true-i.e., whether it effectively corresponds to objective reality-does not mean that aiming at truth is meaningless. And indeed, according to Mäki, much economic discourse is more appropriately understood as an attempt to truly represent the world-even if we can never know with full certitude whether our representations are true. Truth with certitude would correspond to McCloskey's Truth, big T. Mäki emphasises that realism can be understood without

\footnotetext{
${ }^{1}$ The epistemological counterparts to these ontological positions are methodological individualism on the one hand and social determinism on the other. On this, see, for example, Bhaskar (1989, ch. 4).

${ }^{2}$ See Lawson (1997, ch. 19); Bhaskar (1979) calls it the transformational model of social action.

${ }^{3}$ See, for example, Mäki (1988A, 1993A, 1995, 2000).

${ }^{4}$ On this see, for example, Mäki (1989, 1990A, 1990B, 1992A, 1992B, 1994, 1996, 1998A).

${ }^{5}$ Mäki (1993A, p. 28)
} 
reference to Truth, big T. ${ }^{1}$ Furthermore, the fact that economic discourse is characterised by a plurality of perspectives and explanatory purposes does not imply that such discourse is not about objectively existing reality. ${ }^{2}$ It follows that in Mäki's interpretation of rhetoric, economic discourse is thus indeed anchored in some way, but not in any firm grounds of epistemic foundationalism. A scientific realist, Mäki stresses, does not have to believe that a theory is 'a literally true story of what the world is like', as Baas van Fraassen (1980, p. 8) claims.

A second important theme in Mäki's analysis is the distinction between realisticness and realism (Mäki, 1989, 1994, 1998B). The former refers to the representational characteristics of economic theories and of the assumptions on which theories build. Economists often speak of 'realism' when they mean realisticness. It is, however, crucial to separate the two, in particular because a realist philosophy does not commit one to use only realistic theories and assumptions. Furthermore, the examination of the issue of assumptions reveals the place of ontological reasoning in economic theorising.

Exploring the reasons for introducing unrealistic assumptions, Mäki (1994) first distinguishes between 'core' assumptions and 'peripheral' assumptions. The former constitute the theory. An example is the hypothesis of utility maximisation characteristic of much of today's economic theory. Core assumptions are often selected in terms of what are believed to be the essential elements, the key factors of the economic activities to be explained. They are thus often seen as being at least partially true. But this does not imply that within the discipline of economics there is consensus on these assumptions. Quite the contrary: Mäki's taxonomy of assumptions illuminates why debates that evolve around core assumptions tend to be the most divisive. Peripheral assumptions may serve several functions. A main question is whether unrealistic assumptions are introduced to help isolate what are believed to be the essential features of the economic activity in question or whether they are introduced to improve the tractability of the theory. The latter is not to be interpreted solely negatively. But it may become problematic, if the only goal is to facilitate the formal tractability of a theory by squeezing it into a pre-existing framework. ${ }^{3}$

This re-examination of the assumptions' issue suggests that economists should pay greater attention to ontological considerations. It also reveals that belief in the truth of a theory or statement and the pursuit of truth are important characteristics of scientific discourse in economics.

\section{The search for an alternative framework for economic methodology}

It is time to pull the threads together. A comparative study of rhetoric and realism is possible from many angles. Examples are: how to describe most accurately the current

\footnotetext{
${ }^{1}$ On this, see Mäki (1993A, pp. 37ff.; 1995).

${ }^{2}$ Mäki (1993A, p. 41) writes: A realist perspective is compatible with thinking of reality itself 'as extremely varied and complex, as having many faces and many deep structures quite objectively, and then to think of human cognition as paying attention to any one or more of them in turn, depending on purpose or perspective.'

3 Though no doubt largely in agreement with Mäki's points about the role of assumptions in relation to abstraction, and in bringing out the essential features of an activity or event to be explained, Lawson believes that Mäki's 'method of isolation' is going too far by neglecting the constraints on explanation that emerge from the particular ontology of the social realm. From the point of view of critical realism, the attempt to construct closed worlds is a non-starter. See Lawson (1997, p. 131ff.); see also Lawson (1998). The disagreement is in part one about the scope of economic methodology: whether it should describe what economists are doing, or whether it should provide a critical standpoint. Boylan and O'Gorman (1995, p. 129) compare Lawson's and Mäki’s approaches along these lines.
} 
situation in economics; how economists do or should explain, the question of 'unobservable' entities in the economic realm; the role of metaphors in scientific argumentation, etc. ${ }^{1}$ I propose to focus on the implications for a concept of knowledge acquisition and evaluation. I am convinced that it is in this respect that the rhetoric vs realism debate in economic methodology has raised the most important challenges. ${ }^{2} \mathrm{~A}$ comparative analysis reveals, however, that we are not yet in a position to answer the questions raised.

\subsection{Beyond positivist epistemology}

We have seen that all parties to the debate agree that the Popperian framework dominating mainstream methodology is an inadequate account of science-not just of economics, but of the natural sciences as well. The unifying theme in the rhetoric vs realism debate is to leave behind Popperian notions of what economics should look like and what constitutes 'good' economic argumentation. But what are the alternatives? How should we think about the science of economics and how could or should we envisage the process of knowledge acquisition and evaluation? Of course, these questions are not new to economic methodology. The perspective taken here is that of a discussion internal to the rhetoric vs realism debate as it has been taking shape with accelerated speed in recent years.

The project of characterising scientific knowledge through epistemological rules was dismissed from both sides of the rhetoric vs realism debate. The rhetorical perspective is that there are no grounds for discriminating between scientific and other kinds of knowledge in the way positivism envisaged. It is argued that since the production of knowledge is necessarily taking place in a discourse, the only metatheoretical framework that is necessary is an ethical one-that of Sprachethik. Its role is to ensure that persuasion is uncoerced.

The defenders of realism in economics share the view that knowledge is socially constructed and thus fallible and historically situated. But from their perspective, the main problem with the positivist heritage lies elsewhere, i.e. in the neglect of ontological considerations that is coupled with the emphasis given to epistemology. Because of its declared anti-realism, the rhetoric approach is accused of falling into the same trap. What is McCloskey's response to this objection?

McCloskey insists on anti-realism insofar as epistemological realism is concerned. Discussing some of Mäki's objections to rhetoric, she makes clear that she is not denying ontological realism. ${ }^{3}$ Approvingly, she quotes from Richard Rorty: 'The world is out there, but descriptions of the world are not' ${ }^{4}$ Since neither Lawson nor Mäki is advocating epistemological realism, there is agreement up to that point. But McCloskey parts from the realists in that she maintains that ontological realism is without effect on the scientific discourse because we cannot break out of the discursive nature of how knowledge is produced. McCloskey (1994, p. 205) thus prefers 'to "bracket” the matter of realism'.

\footnotetext{
${ }^{1}$ One line of criticism of (critical) realism is that it does not add anything new to how economists argue anyway. This is, for example, Backhouse's (1997) and Hausman's (1998) view. Hausman as well as Mäki (1996) argue furthermore that the emphasis critical realism gives to 'unobservables' is inadequate in the case of economics. Boylan and O'Gorman (1995) are also critical of unobservables. They put forward an alternative to both realism and rhetoric that they call 'causal holism' and which emphasises description over explanation.

${ }^{2}$ Indeed, many of the book reviews of Economics and Reality stress this topic. See, for example, Dow (1997B) or Mote (1997).

${ }^{3}$ McCloskey (1988) and, in more detail, McCloskey (1994, pp. 199-205).

${ }^{4}$ Rorty (1989, p. 5), quoted in McCloskey (1994, p. 200).
} 
Lawson and Mäki disagree: ontological realism does matter; it cannot be bypassed. But they also disagree with each other on how it matters. Mäki argues that it is the realist perspective that allows us to understand the substance of economic debates. His objection to the rhetoric approach is that - at least so far-it has given too much attention to how economists argue, but too little to the question what they are arguing about. ${ }^{1}$ This neglect is not accidental, in Mäki's view. It is the result of the explicitly anti-realist foundation of McCloskey's interpretation of the rhetoric project. Furthermore, he disagrees with McCloskey that embracing ontological realism leads to a foundationalism of some sort. In his view, ontological realism does not as such decide anything. As his analysis of the assumptions issue has shown, the realist perspective gives us a tool to understand the most ardent debates in economics as having their origins in a disagreement about what constitutes the essence of economic activities. ${ }^{2}$

Compared with Mäki's version of realism, in critical realism ontology plays a more prescriptive role since it suggests a particular ontology as the basis for economic theorising. The thrust of critical realism - inspired at least in part by the argument for transcendental realism in the natural sciences-is that to be a successful science, explanation in economics needs to take into account the specific ontology of the social realm it suggests. Economic explanation should be geared towards uncovering the mechanisms and social structures which bring about the actual phenomena we observe.

But it is important to note what role critical realism assigns to ontology in the assessment of economic theories. Ontological reasoning cannot, in itself, discriminate between contrasting explanations. At this level, critical realism recognises the role of discourse. To expect more from ontological reasoning, would amount to an 'ontic fallacy', the pendant to the 'epistemic fallacy'. ${ }^{3}$

While there is disagreement with respect to the alternatives to positivist epistemology at the level of methodology, there seems to be increasing agreement among all parties at the level of the impact of deductivism on the substance of economic theory. In contrast to The Rhetoric of Economics, where McCloskey was inclined to award a satisfactory grade to economic theorising, she increasingly attacks deductivism for being far more than a superfluous rhetorical distortion. Her most recent book, in particular, makes this clear. The style of her argumentation as well as the themes of her criticisms have remained the same. But increasing attention is given to the relation between economic theorising and 'the real world'. This shift brings her closer to both Mäki's call for more substantive

\footnotetext{
${ }^{1}$ Boylan and O'Gorman (1995, p. 51) also note this problem. They introduce the distinction between 'global' and 'local' rhetoric. They favour the latter, which-in contrast to McCloskey's global rhetoricleaves room for other considerations besides rhetoric.

${ }^{2}$ McCloskey (1995) objects to Mäki's (1995) argument that it suggests that one is forced to choose between a correspondence and a coherence theory of truth, while she would not want to commit herself to either. McCloskey's objection is, however, slightly besides the point since Mäki's argument hinges less on a particular definition of truth, than on the role of a realist notion of truth in economic discourse. The position Mäki argues against is well-expressed in the following quotation from Klamer (1984B, p. 253; my emphasis): 'One major lesson for good and effective economists is that a detached and neutral attitude does not make an interesting and persuasive economist. As well as having a stance or a vision, a good economist has to demonstrate the ability to argue in terms that other economists can appreciate. It is tempting to argue from common sense, but one has to speak the technical language of economists to get their attention: empirical arguments, uncertain as they may be, are a necessity. This is the social factor at work. Does the uncertainty mean that economic knowledge is altogether subjective and lacks truth content? We are not sure, but I doubt whether the answer matters much.'

${ }^{3}$ This is discussed in Bhaskar (1989, pp. 157ff.). See also Bhaskar (1986). Boylan and O'Gorman (1995) take issue with this problem and argue that because of the inconclusiveness of explanation, economics should be a purely descriptive science (cf., n. 44).
} 
analysis of economic theories and Lawson's claim that the consequence of deductivism in economic theories is irrelevance. In other words, while some agreement can be identified about what should change in the ways economists argue, there is little agreement as to how this change is best achieved.

The essence of the disagreements can be stated as follows. Mäki argues that the very possibility of substantive critical assessment of economic theories in economic methodology derives from the search for truth, from the attempt to uncover aspects of an objectively existing reality that characterises the endeavour of the economic discipline. This is not given in an anti-realist interpretation of rhetoric. Lawson agrees with this, but critical realism goes one step further. It links the current state of economic theorising to the deductivist methodology and to the failure to take into account the ontology of the social realm. His view is that insofar as mainstream economists are searching for truth, they are searching in the wrong place. In contrast to critical realism, for McCloskey it is not ontology, but the rhetoric of positivism that tends to lead economists astray. It unduly favours some forms of (bad) argumentation and arbitrarily excludes others, in particular those of a more historical and interpretative nature.

\subsection{Science, legitimacy and rationality}

At this point, we have perhaps reached the most serious deadlock in the rhetoric vs realism controversy. It can be further illuminated in the following way. Positivism attached the legitimacy of scientific knowledge to epistemological standards, and it equated legitimacy with the rationality of the scientific enterprise. While McCloskey rejects the idea of rational science, Mäki and Lawson are not ready to give it up. Lawson (1997, p. 246; my emphasis) writes:

In short, fallibility of knowledge neither rules out the possibility of truth in knowledge-and certainly does nothing to devalue its pursuit-nor does it license the absurd fictions of academic economics, sometimes construed as if more or less anything goes. Rather, the acceptance of ontological realism places the constraint of extra-discursive reality upon what can legitimately be maintained. A commitment to (ontological) realism, combined with epistemological relativism sustains a judgmental rationality, and from this perspective the practices of contemporary economic modeling are found to be wanting.

(Critical) realism is invoked as a corrective force ensuring the ongoing rationality of the scientific discourse. In a similar vein, Mäki objects to McCloskey that her framework offers no safeguards against arbitrariness. The actual discourse in economics does not bear much resemblance with a discourse that is herrschaftsfrei in Habermas' sense. But this would be necessary to make sure that persuasion is indeed uncoerced and thus a criterion for valid argumentation. Despite this situation, Mäki argues, McCloskey seems largely approving of the economic discourse - at least in her earlier work. He concludes:

We have ended up with a very interesting situation regarding McCloskey's coherence theory of truth. First, the social constraint imposed in assessments of truth or 'rightness' . . is left without theorized grounding, moral or otherwise. The door is open for rightness or plausibility or truth being conditioned by any kind of social factors, pure political power included. Secondly, [it] replaces the classical notion of basing knowledge upon privileged, unquestioned epistemic foundations by the idea of basing knowledge on privileged, unquestioned social foundations. ${ }^{1}$

Mäki claims that a realist foundation for rhetoric, in the way he imagines it, is necessary to prevent scientific discourse in economics from sliding into pure arbitrariness.

${ }^{1}$ Mäki (1993A, p. 35). On these issues, see also Mäki (1995) and Mäki and Vromen (1996). 
To summarise the positions, it can be said that for McCloskey, the legitimacy of scientific knowledge hinges on accountability to peers. A legitimate argument is one that the participants in an orderly discourse - the community of economists respecting the norms of Sprachethik - find persuasive. For Lawson and Mäki, this is not sufficient. They argue that accountability to peers needs to be supplemented, if not replaced, by what may be called accountability to reality.

The hopes placed on rational science are particularly evident in the case of critical realism and are expressed most clearly in the chapter of Economics and Reality entitled 'Economic Policy and Intended Change'. ${ }^{1}$ There Lawson elaborates on the role critical realism could play in political discourse and develops the concept of explanatory critique that follows from critical realism. It is worthwhile quoting Lawson's view at length. Explanatory critique, he explains,

is a situation in which beliefs are shown to be inadequate to their situation. This scenario focuses on a critical possibility, available only to social (i.e. not to natural) science, wherein it may be possible to transform a set of structures through facilitating a change in the manner in which each is understood. (Lawson, 1997, p. 277)

The difference between the natural sciences and the social sciences has to do with the unchanging nature of the mechanisms operating in the natural realm, and the interlinkage between social structures and human agency in the social realm that was mentioned earlier. The term 'critical realism' has been chosen to reflect the potential of the social sciences to influence social structures. The passage just quoted thus continues as follows.

Specifically, it lies within the potential of social science both to identify discrepancies between social objects and general beliefs about and expectations of, or relevant to, those objects and also to provide an explanation of such discrepancies, i.e. to identify the social cause responsible. When this is achieved the basis is clearly laid for the possibility (although it will never be sufficient for the realisation) of rational, intentional, social transformation, in particular through a modification of the practices on which the structures of relevance depend. (ibid.)

In other words, if economics were to become a successful science in the spirit of the natural sciences, the potential for policy interventions from economists would be enhanced. By virtue of the way scientific knowledge is produced, economics could help uncover false beliefs about social structures and thus contribute to their reform.

What echoes in the passage quoted is the theme of 'false consciousness', as well as its associated (modernist) belief that science can produce the kind of knowledge needed to correct these biases. It seems that while the realist position in economic methodology is defended as necessary to maintain a critical element about the substance of economic theory, it is rather uncritical about the status of science and of scientific knowledge in society. But from positivism, we have inherited not only a notion of what scientific reasoning should look like, but equally, as McCloskey's critique has made abundantly clear, a notion of the status of science and of scientific knowledge in society. ${ }^{2}$

But are the norms of Sprachethik in the way that McCloskey interprets them sufficient, even if the ideal case is assumed where they are fully implemented? Let me discuss one case in point here. One of McCloskey's main arguments against (Methodological) rules for scientific discourse besides those of Sprachethik is that they will inevitably become rigid over time. This argument applies equally to the way metaphors are used in economic

\footnotetext{
${ }^{1}$ See also Lawson (1999) for a further elaboration

${ }^{2}$ The critiques of critical realism of Baert (1996) and Kanth (1999) focus on similar issues.
} 
discourse. They have an equal tendency to become rigid and thus-by way of the view of the world they entail-lead to discrimination against some forms of reasoning. What can Sprachethik as McCloskey interprets it set against that? Not much.

To be fair, McCloskey does call attention to the danger of 'dead' metaphors. ${ }^{1}$ But what if they are not 'dead' in the sense that a significant part of the scientific community still finds them productive? They can nevertheless work against some views which run counter to the way of reasoning embodied in these metaphors. Recall Mäki's analysis of the assumptions issue. It shows how debates in economics often have at their origin a disagreement about what constitutes the essence of economic activities. Furthermore, much heterodox work in economics is dedicated to the critique of the world view embodied in the dominant language in economics. ${ }^{2}$ A particularly vivid example is the work done in feminist economics. ${ }^{3}$

Taking the rhetorical nature of economics seriously in the way McCloskey advocates no doubt facilitates a greater plurality of perspectives. But as long as it relies only on a thin concept of legitimacy such as her notion of 'Sprachethik', it provides no guideline to decide which perspectives should be heard. It seems as if one of the most fundamental weaknesses of the rhetoric approach is that it has not much to set against an economic discourse that is becoming increasingly self-referential. If the standard for validity of scientific arguments depends on the persuasion of those within the scientific community, McCloskey's rhetoric for economics, as Mäki has rightly pointed out, may slide into arbitrariness. This shows the need to go beyond accountability to peers and to re-think the question of what constitutes valid argumentation in economics in a way that is perhaps more radical than McCloskey is willing to grant.

This brings me back to the aim of maintaining a critical element in economic methodology about the substance of economic theories. My question here is: is realism necessarily the only framework that can guarantee this critical element? To illustrate my point, let us first look again at the idea of 'false consciousness' that seems to be alive in critical realism. On what grounds and to what extent can we assume that the process of knowledge production in (social) science is superior and is able to correct false beliefs? While I agree that ontological considerations are important and help to ensure that economic discourse does not forget its purpose, I do not think that as such, ontological realism exhausts the question of what constitutes legitimacy in knowledge acquisition and evaluation. Just like the rhetoric approach, realism also neglects the issue of whose perspective should be included in the scientific discourse. Stressing the accountability to reality and its rationalising force in the process of knowledge production is not enough if there is a plurality of cognitive processes through which 'reality' is perceived and constructed.

The problem is emphasised by the theoretical issues raised by (empirical) social studies of science and the theoretical discipline of social epistemology. Mäki (1992C, 1993C) has started to tease out the potential implications of such research for economic methodology without, however, addressing the point just mentioned. Similarly, while Lawson (1999) attempts to answer the concerns of feminist economics and feminist epistemology-the latter being a major driving force behind the project of social epistemology-the answer remains incomplete. Lawson suggests that the importance of contrastive demi-regs

\footnotetext{
${ }^{1}$ See McCloskey (1985, ch. 5).

${ }^{2}$ See, for example, Heilbroner (1990) for a discussion of the relation between the rhetoric approach and such critique.

${ }^{3}$ For methodological discussions in feminist economics, see, for example, Folbre and Hartmann (1988), Nelson (1992, 1996), Strassman (1993).
} 
underlines the need to include a variety of perspectives in the process of knowledge acquisition and as such is in line in particular with feminist standpoint epistemology. ${ }^{1}$ But we have no grounds for deciding which perspectives should be included. It seems, therefore, that what we need is an interpretation of accountability in the process of knowledge production that is broader than both the rhetoric and realism approaches have been willing to envisage so far.

The rhetoric vs realism debate has led to a shift in thinking about what would be the appropriate meta-theoretical framework for economics. There is agreement that the epistemological framework inherited from the positivist tradition is inadequate. It has been argued here that the debate can be read as an invitation to reconsider the question of what framework is necessary to ensure the validity of arguments in economics. At its current stage, the debate has not exhaustively answered this question. In particular, it remains silent on what framework is necessary to prevent hegemony in scientific discourse. As a result of the attempt to overcome positivist epistemology, the rhetoric vs realism debate has not yet led to a more critical and progressive rethinking of epistemological issues. It will be important, however, to pursue these issues further, since they will affect not just the self-understanding of the discipline but also the status of economics as a 'science' in broader social discourse.

\section{References}

Amariglio, J. L. 1990. Economics as a postmodern discourse, pp. 15-46 in Samuels, W. J. (ed.), Economics as Discourse, Dordrecht, Kluwer

Archer, M., Bhaskar, R., Collier, A., Lawson, T. and Norrie, A. (eds) 1998. Critical Realism: Essential Readings, London, Routledge

Backhouse, R. 1994. New Directions in Economic Methodology, London, Routledge

Backhouse, R. 1997. 'Uncritical Realism', mimeo

Baert, P. 1996. Realist philosophy of the social sciences and economics: a critique, Cambridge Fournal of Economics, vol. 20, no. 5, 513-22

Bhaskar, R. 1978. A Realist Theory of Science, 2nd edn, Brighton, Harvester

Bhaskar, R. 1979. The Possibility of Naturalism, 3rd edn, London and New York, Routledge, 1998

Bhaskar, R. 1986. Scientific Realism and Human Emancipation, London, Verso

Bhaskar, R. 1989. Reclaiming Reality, London, Verso

Blaug, M. 1980. The Methodology of Economics; or How Economists Explain, Cambridge, Cambridge University Press

Boylan, T. A. and O'Gorman, P. F. 1995. Beyond Rhetoric and Realism in Economics, London and New York, Routledge

Caldwell, B. J. 1982. Beyond Positivism: Economic Methodology in the Twentieth Century, London, Allen \& Unwin

Caldwell, B. J. and Coats, A. W. 1984. The rhetoric of economists: a comment on McCloskey, Fournal of Economic Literature, vol. 24, 575-8

Collier, A. 1994. Critical Realism: An Introduction to Roy Bhaskar's Philosophy, London, Verso

Davidson, D. 1980. Essays on Action and Events, Oxford, Clarendon

Dow, S. C. 1997A. Mainstream economic methodology, Cambridge fournal of Economics, vol. 21, no. 1, 73-93

Dow, S. C. 1997B. Economics and Reality (book review), New Political Economy vol. 2, no. 3, $527-31$

Feyerabend, P. 1975. Against Method: Outline of an Anarchistic Theory of Knowledge, London, Verso Fleetwood, S. 1999. Critical Realism in Economics: Development and Debate, London and New York, Routledge

\footnotetext{
${ }^{1}$ On feminist standpoint epistemology, see Harding (1991, 1992).
} 
Folbre, N. and Hartmann, H. 1988. The rhetoric of self-interest: ideology and gender in economic theory, pp. 184-203 in Klamer, A., Solow, R. M. and McCloskey, D. N. (eds), The Consequences of Economic Rhetoric, Cambridge, Cambridge University Press

Friedman, M. 1953. The methodology of positive economics, pp. 3-43 in Essays in Positive Economics, Chicago, Chicago University Press

Habermas, J. 1968 [1971]. Knowledge and Human Interests, English transl., Boston, Beacon

Harding, S. 1991. Whose Science? Whose Knowledge? Ithaca, Cornell University Press

Harding, S. 1992. Rethinking standpoint epistemology: what is 'strong objectivity'? Centennial Review, vol. 36, no. 3, 437-70

Hausman, D. 1998. Problems with realism in economics, Economics and Philosophy, vol. 14, no. 2

Heilbroner, R. 1990. Economics as ideology, pp. 101-16 in Samuels, W. (ed.), Economics as Discourse, Boston, Kluwer

Henderson, W., Dudley-Evans, T. and Backhouse, R. (eds) 1993. Economics and Language, London and New York, Routledge

Kanth, R. 1999. Against Eurocentred epistemologies: a critique of science, realism, and economics, Ekonomia, vol. 1, no. 2, 54-74

Klamer, A. 1984A. Conversations with Economists: New Classical Economists and Opponents Speak Out on the Current Controversy in Macroeconomics, Totawa, Rowman \& Allanheld

Klamer, A. 1984B. Levels of discourse in new classical economics, History of Political Economy, vol. 16 , no. 2, 263-90

Klamer, A. 1988A. Economics as discourse, pp. 280-93 in de Marchi, N. (ed.) The Popperian Legacy in Economics, Cambridge, Cambridge University Press

Klamer, A. 1988B. Negotiating a new conversation about economics, pp. 265-79 in Klamer, A., Solow, R. M. and McCloskey, D. N. (eds), Consequences of Economic Rhetoric, New York, Cambridge University Press

Klamer, A., Solow, R. M. and McCloskey, D. N. (eds) 1988. Consequences of Economic Rhetoric, New York, Cambridge University Press

Lacey, A. R. 1986. A Dictionary of Philosophy, 2nd edn, London, Routledge

Latour, B. and Woolgar, S. 1979. Laboratory Life: the Construction of Scientific Facts, 2nd edn, Princeton, Princeton University Press, 1986

Lawson, T. 1987. The relative/absolute nature of knowledge and economic analysis, Economic Fournal, vol. 97, 951-70

Lawson, T. 1989. Abstraction, tendencies and stylised facts: a realist approach to economic analysis, Cambridge Fournal of Economics, vol. 13, no. 1, 59-78

Lawson, T. 1992A. Realism, closed systems and Friedman, pp. 149-69 in Samuels, W. J. and Biddle, J. (eds) Research in the History of Economic Thought and Methodology, vol. 10, Greenwich, CT and London, JAI Press

Lawson, T. 1992B. Methodology: non-optional and consequential, Royal Economic Society Nerwsletter, October

Lawson, T. 1994. A realist theory for economics, pp. 257-85 in Backhouse, R. (ed.), New Directions in Economic Methodology, London, Routledge

Lawson, T. 1995A. The 'Lucas critique': a generalisation, Cambridge fournal of Economics, vol. 19, no. 2, 257-76

Lawson, T. 1995B. Economics and expectations, pp. 77-106 in Dow, S. C. and J. Hillard (eds), Keynes, Knowledge and Uncertainty, Aldershot, Edward Elgar

Lawson, T. 1997. Economics and Reality, London, Routledge

Lawson, T. 1998. Clarifying and developing the Economics and Reality project: closed and open systems, deductivism, prediction, and teaching, Review of Social Economy, vol. 56, no. 3, 356-75

Lawson, T. 1999A. Feminism, realism, and universalism, Feminist Economics, vol. 5, no. 2, 25-59

Lawson, T. 1999B. Critical issues in economics as realist social theory, Ekonomia, vol. 1, no 2, $75-117$

Lawson, T. 1999C. Connections and distinctions: Post Keynesianism and critical realism, fournal of Post Keynesian Economics, vol. 22, no. 1

Mäki, U. 1988A. How to combine rhetoric and realism in the methodology of economics, Economics and Philosophy, vol. 4, no. 1, 89-109

Mäki, U. 1988B. Realism, economics, and rhetoric: a rejoinder to McCloskey, Economics and Philosophy, vol. 4, no. 1, 167-9 
Mäki, U. 1989. On the problem of realism in economics, Ricerche Economiche, vol. 43, no. 1-2, 176-98

Mäki, U. 1990A. Studies in Realism and Explanation in Economics, Helsinki, Suomalainen Tiedeakatemia

Mäki, U. 1990B. Scientific realism and Austrian explanation, Review of Political Economy, vol. 2

Mäki, U. 1992A. Friedman and realism, pp. 171-95 in Samuels, W. J. and Biddle, J. (eds), Research in the History of Economic Thought and Methodology, vol. 10, Greenwich, CT and London, JAI Press

Mäki, U. 1992B. On the method of isolation in economics, in Dilworth C. (ed.), Poznan Studies in the Philosophy of the Sciences and the Humanities, special issue on Intelligibility in Science, Amsterdam, Rodopi

Mäki, U. 1992C. Social conditioning of economics, pp. 65-104 in de Marchi N. (ed.), PostPopperian Methodology of Economics, Boston, Kluwer

Mäki, U. 1993A. Two philosophies of the rhetoric of economics, pp. 23-50 in Henderson, W., Dudley-Evans, T. and Backhouse, R. (eds), Economics and Language, London and New York, Routledge

Mäki, U. 1993B. Economics with institutions: an agenda for methodological enquiry, pp. 3-42 in Mäki, U., Gustafsson, B. and Knudsen, C. (eds), Rationality, Institutions and Economic Methodology, London and New York, Routledge

Mäki, U. 1993C. Social theories of science and the fate of institutionalism in economics, pp. 76-109 in Mäki, U., Gustafsson, B. and Knudsen, C. (eds), Rationality, Institutions and Economic Methodology, London and New York, Routledge

Mäki, U. 1994. Reorienting the assumptions issue, pp. 147-68 in Backhouse, R. (ed.), New Directions in Economic Methodology, London and New York, Routledge

Mäki, U. 1995. Diagnosing McCloskey, fournal of Economic Literature, vol. 33, no. 3, 1300-18

Mäki, U. 1996. Scientific realism and some peculiarities of economics, in Cohen, R. S., Hilpinen, R. and Renzong, Q. (eds), Realism and Anti-realism in the Philosophy of Science, Dordrecht, Kluwer

Mäki, U. 1998A. Aspects of realism about economics, Theoria, vol. 12, no. 2, 301-19

Mäki, U. 1998B. Is Coase a realist? Philosophy of the Social Sciences, vol. 28, no. 1, 5-31

Mäki, U. 2000. 'Performance against dialogue, or answering and really answering: a participant observer's reflections on the McCloskey conversation. Fournal of Economic Issues, vol. 34, no. 1, 43-59.

Mäki, U. and Vromen J. 1996. 'How far is Chicago from Frankfurt?' mimeo, Rotterdam, Erasmus University

McCloskey, D. N. 1983. The rhetoric of economics, fournal of Economic Literature, vol. 21, 434-61.

McCloskey, D. N. 1985. The Rhetoric of Economics, Madison, University of Wisconsin Press

McCloskey, D. N. 1986. The Writing of Economics, New York, Macmillan

McCloskey, D. N. 1990. If You're So Smart: the Narrative of Economic Expertise, Chicago, University of Chicago Press

McCloskey, D. N. 1994. Knowledge and Persuasion in Economics, Cambridge, University of Cambridge Press

McCloskey, D. N. 1995. Modern epistemology against analytic philosophy: a reply to Mäki, fournal of Economic Literature, vol. 33, 1319-23

McCloskey, D. N. 1996. The Vices of Economists-The Virtues of the Bourgeoisie, Amsterdam, Amsterdam University Press

Mote, J. E. 1997. Economics and Reality (book review), fournal of Economic Issues, vol. 31, no. 4

Nelson, J. A. 1992. Gender, metaphor, and the definition of economics, Economics and Philosophy, vol. 8 , no. 1, 103-25

Nelson, J. A. 1996. Feminism, Objectivity, and Economics, London, Routledge

Outhwaite, W. 1987. New Philosophies of Social Science: Realism, Hermeneutics and Critical Theory, Basingstoke and London, Macmillan

Rappaport, S. 1988. Economic methodology: rhetoric or epistemology? Economics and Philosophy, vol. 4, no. 1, 110-28

Redman, D. A. 1991. Economics and Philosophy of Science, New York, Oxford University Press

Rorty, R. 1989. Contingency, Irony, and Solidarity, Cambridge, Cambridge University Press

Rosenberg, A. 1988. Economics is too important to be left to the rhetoricians, Economics and Philosophy, vol. 4, no. 1, 129-49 
Rossetti, J. 1992. Deconstruction, rhetoric, and economics, pp. 211-34 in de Marchi, N. (ed.), PostPopperian Methodology, Boston and Dordrecht, Kluwer and Neijhoff

Samuels, W. J. (ed.) 1990. Economics as Discourse. An Analysis of the Language of Economics, Boston, Kluwer

Scheman, N. 1991. Who wants to know? The epistemological value of values, in Hartman, J. E. and Messer-Davidow, E. (eds), (En) Gendering Knowledge: Feminists in Academe, Knoxville, University of Tennesse Press

Strassman, D. 1993. Not a free market: the rhetoric of disciplinary authority in economics, pp. 54-68 in Ferber, M. A. and Nelson, J. A. (eds), Beyond Economic Man, Chicago and London, University of Chicago Press

Van Fraassen, B. C. 1980. The Scientific Image, Oxford, Clarendon 
